\title{
KENNETH BURKE'S ENCOUNTERS WITH WALT WHITMAN
}

\author{
William H. RUeCKerT
}

OUR PROJECT HERE is to examine the relationship between Kenneth Burke (a twentieth-century American critic and sometime poet) and Walt Whitman (a nineteenth-century American poet and sometime critic). This is not going to be an "influence" study, nor is it going to deal with the "anxieties of influence" in the usual sense of this phrase. The justification for this project is that both Burke and Whitman are major American writers from different centuries; that both were specifically concerned with America, with what it means to be an American writer, with democracy, and with capitalism; that Burke wrote a fair amount about Whitman as well as a number of explicitly Whitmanian poems; and that it is always useful and illuminating to bring great American writers from different centuries together. Coincidentally, both were self-taught, highly idealistic, remarkable word men, and they shared New Jersey as their adopted home.

I.

Burke first wrote about Whitman in Attitudes Toward History (1937) in the opening section of that book entitled "Acceptance and Rejection." The section deals with "frames of acceptance" and discusses, briefly, William James, Walt Whitman, and Ralph Waldo Emerson. Whitman is discussed as the "poetic replica of James" and is used to illustrate what Burke means by pluralism and "frame of acceptance." The Whitman that Burke draws upon is basically the "Song of the Open Road" Whitman. Burke's treatment of Whitman here is somewhat superficial and contains nothing substantive about Whitman or his poetry. Whitman, like James and Emerson, is mostly used to get this book underway and to provide ready concrete examples of "acceptance" as an attitude toward history. If Burke had made any significant contact with Whitman by 1937, it is not obvious in this brief treatment of him. ${ }^{1}$

The same can be said for the two brief references to Whitman in The Philosophy of Literary Form (1941). ${ }^{2}$ One of these references is worth noting, though, because in it Burke identifies an idea in Whitman which he will later use in his twentieth-century "attack" on Whitman's nineteenth-century vision: Burke points out that Whitman constantly justified the destruction of our seemingly limitless natural resources in the name of progress, which, of course, is perfectly true. To the best of my knowledge, Whitman is never 
mentioned in either A Grammar of Motives (1945) or A Rhetoric of Motives (1950)-presumably because Burke had not yet read Whitman in any serious way.

Burke's first serious encounter with Walt Whitman is in his long essay, "Policy Made Personal: Whitman's Verse and Prose-Salient Traits" in Leaves of Grass One Hundred Years After (1955). ${ }^{3}$ When Burke wrote this essay he had finished the first two volumes of his projected tetralogy of Motives (the Grammar and Rhetoric) and was working on his poetics (or as he was to call it, his Symbolic of Motives). The essay on Whitman is conceived and written within the context of Burke's dramatistic poetics. I point this out because what Burke tries to do with Whitman is determined by his need (or desire) to work out his own poetics, and the emphasis in the essay is equally divided between service to Whitman and service to the poetics. This has always been Burke's way of doing things, and we could say of this essay what Burke said of his own great essay on Othello-that it was an essay to illustrate a method and a poetics. ${ }^{4}$ It is important to note here before turning to the essay itself that the emphasis in this essay is upon the relationship between Whitman's prose and poetry rather than upon his vision, and that many of the things Burke does in the essay are the result of his desire to illustrate one of the basic premises of his poetics - which is that all great literary works are symbolic acts for the author and have a private psychological dimension which can only be gotten at by a careful analysis of the image clusters in the writer's work. When a poet makes a policy (say, Whitman's vision of America) personal he translates it into concrete imagistic terms, drawing his images from the human body, the natural body, and the body politic. But, lest I get lost in Burke's rather complex dramatistic poetics, let me turn to the essay itself and work directly from it.

The essay is divided into Burke's characteristic three-part (plus some kind of an epilogue) structure. Burke often refers to this structure as a trilogy plus a satyr play. In Part I of the essay ("Vistas"), Burke uses "Democratic Vistas" as his text for establishing Whitman's "policy" or vision. He does not use any other prose text, though the 1855 "Preface" would seem like a natural. In Part II ("Leaves"), Burke uses Leaves of Grass (rather selectively but very effectively) to show what happens when the policy is made personal in the poetry. Burke does not analyze individual poems but selects passages from all through Leaves of Grass to establish and discuss some salient image clusters. The analysis of Leaves is very specialized in terms of Burke's own dramatistic coordinates. In Part III ("Lilacs"), he takes the evidence from I and II and applies it in a sustained analysis of "When Lilacs Last in the Dooryard Bloom'd." In other words, in his characteristic fashion, he selects a representative text (a synecdoche) and subjects it to intensive analysis to read the whole. This is certainly the best part of the essay and yields a reading of this great poem any Whitmanian can learn from. In the epilogue, Burke creates a "Whitman Medley" for us by assembling the first lines of fifty-five Whitman 
poems into eight stanzas under the title "First O Songs for a Prelude," which is the first line of the first poem in Drum-Taps. This creates a deliberately comic and playful event as a way of closure to this long and intensely serious essay.

Burke has certainly engaged Whitman here in a most significant way. All .the rest of his serious encounters will derive from this one, though it will be many years before they occur, and they will take very different forms from the basically literary critical encounter of this essay.

It is not a scholarly essay. Though Burke is scholarly and learned, he is not a scholar in the usual sense and relies upon his own genius most of the time, just as he tends to pursue his own interests no matter what he is writing about. He says in his prefatory note to the essay that a better subtitle would be "On Interrelations Among Key Terms in Whitman's Language," and that would in fact describe the main thrust of the essay. Burke is not interested here in the complex history of Leaves of Grass, nor even in the fact that he is writing in the twentieth century about a great nineteenth-century text. That interest comes later in his encounters with Whitman. He is interested in the relationship between prose and poetry, in different kinds of symbolic (verbal) actions, in how ideas (a vision) get embodied in images in poetry. The texts are treated as finished verbal structures which provide one with irrefutable empirical evidence for analysis. Since everything is by the same author, it is all interrelated and coherent. The critic's task is to locate that coherence and try to determine what is really being said. The poems are both private acts and public statements. Burke wants to know what Whitman really meant, what his policy really was. $\mathrm{He}-$ Burke-does not want to act on this policy; he just wants to learn what it is and document it. Later, in his encounters with Whitman, he will be much more interested in action and will have a much stronger personal reaction to Whitman's vision and poetry. But here he is much more interested in examining the texts and in establishing the interrelationships between the key terms in these texts.

Burke's interest here is abstract and clinical. He does not care-or less likely, did not know - that he is dealing with a statement of policy that was written after most of the poetry he discusses as an example of how this policy gets personalized. For Burke the texts exist in a kind of timeless realm of verbal interrelationships, and so the policy could easily have been personalized in poetry before it was codified in prose. It is not so much the before and after that Burke is interested in; what interests him are the different modes of verbal discourse and the fact that the poetry has a psychological fullness and truthfulness that is lacking in the prose. We have to remember that Burke believes that poetry is part of our equipment for living and that it functions covertly for the poet in important and beneficial ways. (This will later prove to be very important when we examine Burke's own long, highly personal and important Whitmanian poem "Eye Crossing-From Brooklyn to Manhat$\tan ^{\prime 5}$-a poem written when his second wife, Libbie, was dying of incurable, 
progressive muscle failure.) Here, in Part II of the essay, of course, he is interested in discovering how Whitman personalized his own private self and democratic policy after the terrible war and the assassination of President Lincoln. Consider the following passages from the essay which demonstrate how abstractly or theoretically Burke deals with the situation of the poem and the poetic strategies Whitman devised to deal with it:

Imagine, then, a situation of this sort: A poet has worked out a scheme for identifying his art with the ideal of a democratic "empire" that he thinks of as a matrix, an All-Mother, a principle of unity bestowing its sanctions upon a strong love of man for man, an "adhesiveness" generally "spiritual," but also made concrete in imagery of "athletic" physical attachment. Quite as God is conceived as both efficient cause and final cause, so this poet's unitary principle is identified with both a source from which he was "unfolded" (the material origins "out of" which his art derived) and an end toward which he "ever-tended" (death, that will receive him by "enfolding" him, thus completing the state of "manifold ensemble" through which he had continually "passed," by repeatedly "coming" and "departing"). A beloved democratic hero has died-and the lyric commemoration of this tragic death will be the occasion of the poem.

How then would he proceed, within the regular bounds of his methods and terminology to endow this occasion with the personal and impersonal dimensions that give it scope and resonance? (For a good poem will be not just one strand, but the interweaving of strands.)

Note, first, that the poem involves several situations. There is the commemorated situation, the death of the hero, as made specific in the journey of the coffin on its last journey. There is the immediate situation of the commemorating poet, among a set of sensory perceptions that he associates, for us, with the hero's death. There is the national scene that he can review, after the fashion of his catalogues, when charting the journey of the coffin (and when radiating into other details loosely connected with this). Near the end, a national scene that had preceded the hero's death will be recalled (the time of civil war, or intestine strife, that had accounted historically for the tragic sacrifice). And in the offering, "over-arching" all, there is the notion of an ultimate scene (life, death, eternity), and a possibility of interrelationships in terms of which immediate sensory images can seem to take on an element of the marvelous, or transcendent, through standing for correspondences beyond their nature as sheerly physical objects). The reader shifts back and forth spontaneously, almost unawares, among these different scenes, with their different orders of motivation, the interpenetration of which adds subtlety and variety to the poem's easy simplicity. ("Policy Made Personal," 101)

I have not made any attempt to summarize what Burke says about Whitman's Vistas, Leaves, and "Lilacs"; it is always best to encounter Burke firsthand so you can follow his complex arguments step by step and experience his massive assemblage of concrete detail from the texts he is dealing with. The full force of his concluding "Whitman Medley" can only be felt by experiencing the huge infusion of Whitman that results when this marvelous entitler and master of opening lines assembles fifty-five glorious first lines of Whitman. My point here is that Burke's encounter with Whitman was serious and profound, though primarily critical and theoretical rather than deeply personal. As a critic, Burke has an amazing essentializing mind, and even when he is pursuing his own theoretical interests (as he most certainly was in this piece), he always tells us wonderfully illuminating things about the texts he is considering. What he says about the maternal cluster in Whit- 
man is not so far-fetched as it at first seems; and the reading of "Lilacs"-the one sustained reading of a whole text in the essay -is brilliant. His justification of the homo-/hetero-erotic imagery and activity in Whitman (it is made necessary by the democratic policy itself) makes a lot of sense when we contemplate as he does the relationship between politics and sexuality (political, social, and sexual wooing are a major theme in his Rhetoric of Motives.).

There is only a brief mention of Whitman in The Rhetoric of Religion (1961). It is in a sub-section of a long essay on "The First Three Chapters of Genesis," which in part is concerned with the circular nature of images as opposed to the rectilinear nature of plots and arguments. The subsection is entitled "'sensory' and 'mythic' images." The maternal image cluster Burke worked up in the 1955 essay is used to illustrate what "mythic" images are and what constitutes circularity. I quote the whole reference to Whitman: "Such [mythic] terms reveal their circularity by the ease with which they shade into other terms. Consider, for instance, how in Whitman such terms as night, mother, death, voyaging, democracy, prophecy, 'blades of grass' and 'songs of myself' cyclically coalesce" $(R R, 254){ }^{6}$ There is not much to be said about this encounter with Whitman: it is in the back room of Burke's mind and is really the reuse of old material.

The same cannot be said for most of the references to Whitman in Language as Symbolic Action (1966). There are six references to Whitman in this long book, and five of them are worth thinking about because they are obviously the result of Burke having thought about Whitman as more than simply the illustration of some point or other. The first two significant references to Whitman come in an essay on Emerson entitled "I, Eye, Ay-Concerning Emerson's Early Essay on Nature' and the Machinery of Transcendence." The first passage is as follows:

All told, however, at their extremes there is a notable difference between tragic catharsis and dialectical transcendence - and the Emerson essay serves as a delightful illustration of this difference. To be sure, the essay is a bit innocuous; but it is delightfully so. It has a kind of exaltation, thanks in large part to Emerson's profuse mixing of his ideas with ingratiating imagery. And we can readily understand why he was so enthusiastic about Whitman, before a more quizzical look at Whitman's poetic evangelism led him to see that it was beckoning "Come hither" to much more than a highly respectable vendor of uplift such as Emerson had bargained for. Both approached the conflicts of the century in terms that allowed for a joyous transcendental translation. To apply in a twisted way (and thereby twisting a twist) Rimbaud's demand for a poetry based on the "reasoned derangement of the senses," we might say that Emerson was as idealistically able as Whitman to look upon traveling salesmen and see a band of angels. (LASA, 189)?

Everything that Burke says in this essay about the dialectic of transcendence could be applied to Whitman, and it is surprising that he did not work more references to Whitman into the essay. But let's examine the two specific references: the first one is about the essential and important similarities and differences between Emerson and Whitman. Burke states this 
difference very nicely, very wittily in a way that is quite similar to Lawrence Buell's more serious statement of it in his wonderful book Literary Transcendentalism $^{8}$ As Buell points out, Whitman went far beyond Emerson in his openness and acceptance of the heroic possibilities of the self, and this allowed him to "indulge and express the chaos of experience that Emerson came to fear" (p. 330). Burke's statement of the major difference between Emerson and Whitman is probably more important than his witty and ironic comment about being able to "look upon traveling salesmen and see a band of angels." I'm not sure Whitman ever did that: when he looked at traveling salesmen he tended to see traveling salesmen, just as, during the Civil War, when he looked at corpses he saw corpses; if he wanted to see angels, he went space traveling, as in Section 33 of "Song of Myself." The dialectics of transcendence in Whitman were not just a matter of optical illusion or delusion, as Burke was to discover.

Burke's next reference to Whitman comes a few pages later (p. 192) and identifies very explicitly his ambivalent response to both Emerson and Whitman. It also epitomizes, I think, the essential twentieth century post-World War II response to both of these writers:

So, if one feels that Emerson's essay is not tough-minded enough (and I'd be the last to assert that it is, for all my love of it), I'd contend that such a judgment is not enough to dismiss it.

If only like loving a pleasant dream, love him for his idealistic upsurge. For it reads well. It is medicine. Even in those days, I feel sure, both he and Whitman suspected that they might be whistling in the dark. But they loved the gesture (if whistling is a gesture)-and it is an appealing gesture, albeit a gesture much more plausible then than now. Emerson's scheme for transcendence (like Whitman's variant) was propounded before his fellow townsmen had lost their sense of a happy, predestined future. There was not yet any crying need to turn, rather, and begin hoarding relics of the ancestral past, like an unregenerate Southerner's attic, with its trunkload of Confederate money. (LASA, 192)

In this passage, we are clearly far beyond the somewhat superficial encounter Burke had with both Emerson and Whitman in 1937. When Burke says that Emerson's essay-and by implication, Whitman's poetry-is not toughminded enough, he means that it does not give us realistic equipment for living in our own time. It might have been good medicine then, but certainly not now. We may love Emerson and Whitman (and love has certainly been one of the most fundamental recurrent responses to the poetry of Whitman, in his time as in our own) but we can no longer believe them, and we are reduced to a kind of purely aesthetic response to both. Knowing that both are like pleasant dreams, we should enjoy them for what they are: we should enjoy the "idealistic upsurge" we get from reading Whitman; and we should enjoy the style. Whitman certainly "reads well" and, yes, it is good medicine, perhaps like an upper, or, since Burke always liked to call the alky he drank "medicine," perhaps reading Emerson and Whitman these days is like having some good drinks. But neither Emerson nor Whitman can be dismissed (or retained) quite so easily. I doubt that either one thought he was whistling in 
the dark. Both had considerable experience of the dark side of life: Whitman had his family, the war, his stroke. Whitman never tried to whistle away the war, as any careful reading of Drum-Taps, Specimen Days, and other postCivil War prose will reveal.

As Burke is fond of saying, it is more complicated than that and he knows it (if only because Whitman's poetry is so deeply, so profoundly political). His later encounters with Whitman confirm just how well he knew it. Burke himself is full of "idealistic upsurges"; his works have passages of splendid idealistic upsurge that rival Whitman and Emerson. They read well. They are good medicine. For all of his irony, Burke is an incurable idealist and is strongly drawn to the likes of Emerson and Whitman. Trying to reconcile idealism (Whitman) to twentieth-century realities is one of the ambiguities of our time. Here, Whitman and Emerson are not being treated just as writers and dealt with in highly abstract and theoretical terms: they have been absorbed and become part of the mind's attempt to understand, confront, and cope with the realities of one's own time. This is clearly the most serious way in which one can read books. All the rest of Burke's encounters with Whitman will be of this kind.

The next reference to Whitman comes in an essay on "Kubla Khan" and is apparently a passing reference to the prevalence of death and paeans to death in Whitman's poetry. Like many of Burke's passing references, there's more to this one than first meets the eye. The reference to Whitman is preceded by the following remarks: "inasmuch as no living poet has experienced death, I take it for granted that, when a poet speaks of death, he is necessarily talking about something else, something witnessed from without, whereas [the] poem is wholly from within" (LASA, 209). Reading this passage one immediately thinks of Emily Dickinson's many poems about death, including her own death - such as "I Felt a Funeral in my Brain." And naturally, in this context, one thinks about Whitman's continual concern with death -from the very beginning (1855) to the very end. Of Whitman's many "paeans" to death, Burke says that they "indicate how Death becomes rather like the ultimate maternal repository from which the forms of conscious life emerge . . " (LASA, 209-210). This is clearly suggestive without being conclusive, as so many of Burke's remarks on poets are, and we can only determine its real value by applying it at more length to the poems. The remark takes us back to the 1955 essay and Burke's encounter with Whitman as a poet, and to the terminological interrelationships he finds in the poems; and, of course, it takes us deep into the whole complex matter of poetic symbolism in Whitman.

The next reference to Whitman is in Burke's wonderful tribute to his friend and fellow poet, William Carlos Williams, who was also one of the contributors to the 1955 volume of essays on Whitman. The relationship between Whitman and Williams as American poets and poets of democracythat is, poets in the American grain-is a large topic, which we cannot ex- 
plore here, but that is what Burke is concerned with. He points out that though both Whitman and Williams were body poets for whom touching was an essential action. Williams's experiences as a doctor "led him to a kind of democracy quite unlike Whitman's, despite the obvious influence of Whitman upon him" (LASA, 284). Yes, but it would take a rather careful analysis of Paterson to show exactly how and why this is true. The general point, I think, would be that twentieth-century democracy is not the same as nineteenth-century democracy, even though Whitman would certainly have loved Williams's "Sunday in the Park" and almost everything else about Paterson. As usual, here, when thinking about Whitman, Burke is thinking in Now and Then terms, not just to isolate the differences, but to assess the relevance. The other remark he makes about the difference between Whitman and Williams is as follows: "In any case, the political editorializing in Whitman's come-one-come-all attitude had lost its meaning, other than as a pleasant sentiment, in proportion as Congress erected legal barriers to the flow of immigrants by a quota system" (LASA, 284). As in other and earlier references to Whitman, Burke is here clearly concerned with the ways in which poets and texts become historical anachronisms and gradually lose some of their meaning as the context of situation (scene) in which they were enacted changes. His response here is not to Whitman the poet but to the enduring relevance of the poetry-or lack of it.

The final reference to Whitman in Language as Symbolic Action comes in Burke's long essay on "A Dramatistic View of the Origins of Language." The nature of the essay guarantees that Whitman is going to be used again for illustrative purposes. Much of this essay is about the negative, which Burke says humans introduced into the world with language. Whitman's life-long, or career-long, attempt to negate the negative-certainly one of the major dialectical actions of his poetry - makes him a natural for Burke in this essay. Unfortunately, only a single paragraph is devoted to one of Whitman's most strenuous attempts to negate the negative: "Song of the Open Road." I quote the whole paragraph while expressing regrets that this great specialist in the negative did not write more here about this ingenious and joyful yea-sayerespecially Section 13 of this ecstatic affirmative poem.

What of Whitman's "Song of the Open Road"? Historically, it preceded traffic conditions as we now know them in the era of the automobile. But the principle of the completely regulated road was already present, in Whitman's time, owing to the fact that the railroad was then the culminative form of travel. Though wrecks were comparatively plentiful, while both safety devices and traffic regulations were comparatively rudimentary, the whole "logic" of railroading was in the direction of more highly developed negatives, as with the elaborate signals and controls on a much-traveled sector of a modern first-class system. So Whitman had had the experience of the regulated range; and he could in imagination combine this with the ideal of free ranging. The combining of such opposites could be celebrated in a "song" of the "open" road, proclaiming a yea that arose from the mounting tangle of nays. Was it medicine, or hysteria? In any case, it could fuse, or confuse, the obsolescent with the future. (LASA, 472) 
I move now to Burke's Whitmanian poems. Burke has been writing poems for most of his adult life (since 1915), but more profusely in his later years (since 1954). Though Burke has written all kinds of poems, two of his more recent long poems are directly indebted to Whitman and are about him. It is these two poems that I want to take up as further examples of Burke's encounter with Walt Whitman. The first of these poems is "Tossing on Floodtides of Sinkership, A Diaristic Fragment" (CP, 277-293), a poem which assumes the reader's familiarity with Whitman's "Song of the Open Road," from which it quotes and upon which it depends for many of its ironic effects. ${ }^{9}$ The date of this poem is probably $1966 / 1967$. Without being too categorical, one could call it a poem of the sixties. It is strongly influenced by the politics of those years, by the environmental movement, and by the Vietnam War. In some very useful prefatory prose remarks about this and other later poems, Burke says that the poem was written in the "run down, postWhitman era" $(C P, 216)$ and that it is concerned, in part, with the poet's relationship to his machines (especially as represented by the Vietnam War), and his self (including his vocation as poet and critic). To these we can add: travel, nature, and the American continent, especially the Western part of it.

The poem is in five parts. Parts I, II, and IV are based upon a transcontinental trip Burke and his wife made by car from Andover, New Jersey to the Northwest. This is what gives the poem its subtitle, since the poem is quite literally composed of fragments of a diary. Part III of the poem is a Whitmanlike catalogue of other cross-country trips (eight, in all, all by car, we are told). Part V is completely different from the rest of the poem and is an account of Burke walking the country roads around his house in Andover, New Jersey. Throughout Parts I, II, and IV Burke is trying to decide what he will lecture about when he gets to the West coast (in other words, Whitman-like, what is he going to tell his audience); more specifically, he is trying to decide what he will tell them about America which, of course, he is seeing first hand on his trip. The automobile is developed into one of the major symbols of the poem, along with travel in general and the road or super-highway (the ultimate open-closed road). Other major symbols are the great natural monuments Burke and his wife visit on their various trips, some of which have survived the assaults of humans and technology, and some of which have not. Niagara Falls - which Burke calls a "pure sewer"-is the prime example of what humans and technology have done to nature and to the great "limitless" American continent Walt wrote so ecstatically about.

The automobile is developed as the symbol of personalized or individualized technological power; and the national monuments-Zion, Yellowstone, the Grand Tetons, the Big Horns, Grand Canyon, Glacier Lake-come to stand for the overwhelming power and grandeur of nature. What we have done to our own country (destroyed and polluted it) is seen in relation to (not 
in contrast with) what we were then doing in Vietnam. If, Burke says, that is the American Dream (Walt's dream), then who could possibly want it anymore? All during the trip Burke is trying to decide what has happened to Walt's dream as he expressed it in the grand lines of "Song of the Open Road" (from which Burke quotes the lines beginning "forever alive, forever forward"), and what he can possibly tell his audience out West (surely Walt's favorite direction, and the direction of Burke's trip) about what he has seen on this trip - the ravages of technology; the perils of overpopulation; the immorality of American imperialism; the power of technology to pollute. How can he talk to them about his ironic run-down, post-Whitmanian perception of and response to Whitman's assertion that if people will just join him on the open road, he can assure them (as he does) that they will "go toward the best, toward something great." Nobody, Burke suggests, can sing Whitman's songs in the twentieth century (as Allen Ginsberg would like to, though he knows that he really can't). Certainly no one, unless he is just indulging in political or poetic rhetoric, or perhaps talking about space travel, can cast the last six sections of "Song of Myself" into twentieth-century terms and mean it, as Whitman most certainly did (in spite of Burke's assertation in this very poem that "Whitman [was] whistling in the dark" [CP, 280]).

Burke repeatedly asks himself what "message" he can take West with him. Not Walt's, that's certain - and that's clearly part of the problem. Burke can't free himself from the responsibilities of being an American (as so many of the rest of us lovers of Whitman can't, though we might like to). Thinking about what we have done to our own country and what we were then doing to Vietnam, Burke hopes that "history proves unjust,"

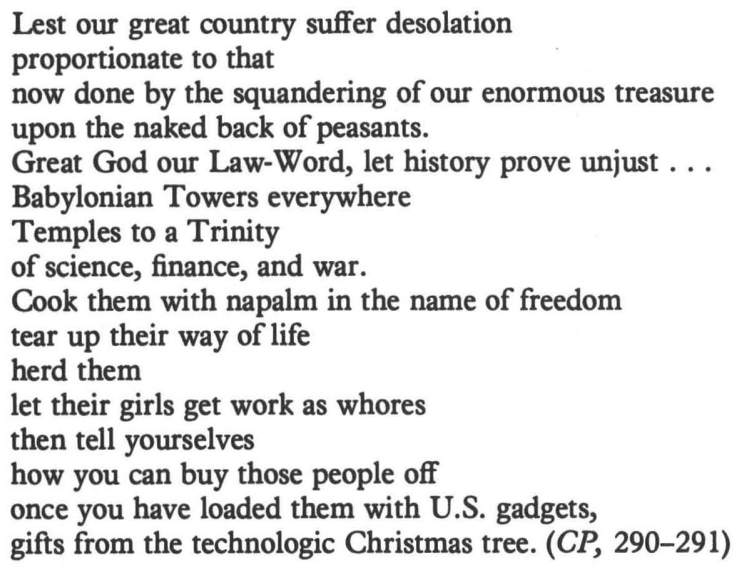

At the end of this section of the poem, Burke decides, in his characteristic ironic fashion, that 
Only this I can say in full authority:

"To be safe in striking at the powerful

make sure your blows are powerless." $(C P, 292)$

Then immediately - first line of Section V-he negates so negative a conclusion and offers us one of his characteristic Whitman-like upsurging closures, in which he appeals to another one of Whitman's major sources of appeal, which is the kind of life that is available to the self. The last section of the poem moves completely away from machines (cars), technology, politics, imperialism, the Vietnam War, pollution (even the spray at Niagara Falls is polluted), national destiny and the justness of history, and moves to the I, the self in a direct relationship to nature.

The first word of Section V is "No," which refers back to the last three lines of Section IV and rejects them. He can speak with authority about some other things and tell his audience something more affirmative, more Whitmanian (though Burke does not put it in these terms). He describes a nighttime walk he took on the country roads around his house in Andover in the spring. He decides that

\footnotetext{
All seasons have their season only if each after its fashion ... only if all seasons lead toward spring.
}

We have to conclude that Burke is not whistling in the dark here any more than Whitman was and that his deeply American belief in the possibility of always being able to begin again is as authentic as Whitman's profound commitment to this same belief, a belief that probably found its most complex expression in Whitman's responses-in Drum-Taps and elsewhere-to the Civil War and the assassination of Lincoln. Burke goes on in Section V to write about our inescapable awareness of our own unique selfhood - which is brought on by hearing the frogs - and of our equally inescapable awareness while walking in nature of how "every eachness merges into allness." One could hardly ask for a more perfect Whitmanian set of perceptions. Finally, he ends the poem with an upsurging image that is repeated (in kind, not exactly) hundreds of times in his poetry and criticism:

seeing every sunset/from every angle/at every instant, and all the while

seeing every sunrise. $(C P, 293)$

We can note, coincidentally, that this image joining beginnings and endings (or endings and beginnings) and ecstasy appears everywhere in Whitman but especially in "Song of Myself," "Song of the Open Road," "Passage to India," and Whispers of Heavenly Death. 
What of the title of this poem: "Tossing on Floodtides of Sinkership, A Diaristic Fragment"? Burke was always a great entitler, so we should pay some attention to this one. "Sinkership" is certainly a punword for the various kinds of sinking dealt with in the poem - the self sinking in a floodtide of grief and shame at the imperialism of its country, the ship of state sinking in a floodtide of misdirected actions and misconceptions of national destiny. It is the poet, Burke, who is obviously tossing on the floodtides of sinkershipthat is, who is caught in the historical storm and in danger of sinking; it is also, I think, America - Whitman's beloved America - that is caught in the historical storm and is tossing on floodtides of sinkership. "Sinkership" surely refers to the policies that make for sinking, the opposite of a term like "statesmanship." The poet is tossing on floodtides of sinkership which he can experience, recognize, acknowledge, analyze, understand, lament but do little about beyond telling people about "them." Technology is going to fulfill its destiny (man's entelechy is technology, Burke has written) and no poet or critic or single human being is going to turn it back or keep it, or the human genius for it, from fulfilling itself. The first four sections of the poem are about this. The poem is a diaristic fragment because it is but a part of a much larger, more comprehensive record Burke has kept. This record would be all of Burke's criticism and poetry and all of the other masses of material he has written and collected on these same subjects.

Finally, the fifth section of the poem is Burke's dialectical other voice asserting that even if he is tossing on floodtides of sinkership, there's still nature, the self, the self's experiences of both nature and itself, the self's awareness that it is part of a larger whole that is perhaps beyond sinkership, the possibility of new beginnings and the diurnal reaffirmation of sunsets, sunrises, and the pleasures of sensory experience. This dialectical other, yea-saying voice does not make the powerfully negative things go away; it simply affirms other possibilities against them. It is not a transcendent voice; that is, it does not function the way Burke says the dialectics of transcendence function in Emerson and Whitman because it does not resolve and transcend the conflict. We might say that it is an unresolved conflict, a doubleness one simply has to live with. This is a crucial difference between Burke and Whitman, and I will return to it later.

We come now to one of Burke's longest, most complex, and most personal poems - "Eye Crossing-From Brooklyn to Manhattan." 10 It is quite different from "Tossing on Floodtides of Sinkership" and represents an entirely different kind of encounter with Walt Whitman. Since Burke-ever the reflexive, self-analytic writer-has provided us with an account of the circumstances under which the poem was written and has written a commentary on the poem, we will begin there. The commentary on the poem is entitled An Eye-Poem for the Ear (With Prose Introduction, Glosses, and After-Words)." Remembering the title of Burke's essay on Emerson-"I, 
Eye, Ay-Concerning Emerson's early Essay on 'Nature' and the machinery of Transcendence"-we can't help but read the first part of the title of the poem as pun-laden, giving us all kinds of clues as to the symbolic action of the poem: I crossing, Eye crossing, and Ay (yea, yes) crossing. That Burke would surround this poem and interlard it with his own critical action is perfect, for it tells us what kind of poem we have here, or it tells us how much the critical and poetic modes interact in Burke, everywhere, to reconfirm the both/and attitude which has been part of his equipment for thinking and living from the very beginning. And finally, the three eyes (I, Ay) are fitting for such a Whitmanian poem, for he was a great poet of all three just as Burke is (the eye for the senses, the I for the self, and the ay for the powerful if always ironic affirmations which have always been part of Burke's criticism and poetry).

The poem was written in the winter of $1968 / 69$ while Burke was living in a hotel apartment in Brooklyn overlooking the New York harbor and the skyscrapers of lower Manhattan. He lived on the same street where Hart Crane lived when he was conceiving and writing parts of The Bridge; and, of course, below the apartment was the river Walt Whitman had crossed by ferry so many times before and after writing "Crossing Brooklyn Ferry." Marianne Moore, to whom the poem is dedicated, was a long-time resident of Brooklyn, a former fellow worker with Burke on The Dial, and a poet he much admired. In his dedication to her he says of her poems that they are "kindly verses" which "give us exceptionally many twists and turns to rejoice about in a lean season" $(D L C, 288)$. It is a lean season because Burke's second wife, Libbie, was dying of progressive failure of the muscle system, a horrible affliction which first immobilizes, then affects speech (the tongue muscle), and finally kills when the tongue and all the other muscles necessary to sustain life fail. All the while, the brain remains clear as the victim becomes more and more helpless. The poem was written while his wife was in the last stages of this illness, and the commentary was written after she died (probably in 1972). The commentary acknowledges this deeply personal dimension of the poem and comments on it as is appropriate in the glosses. However, Burke's wife is never explicitly named or mentioned in the poem, nor is the nature of her illness. If it were not for the commentary we would not know that "eye crossing" (instead of crossing physically by ferry or bridge) is an oblique reference to Burke's sympathetic reaction to his wife's immobility; and, of course, we would not know that the many references to "we" in the poem are to Burke and his wife looking-eye crossing-to Manhattan.

I will combine my analysis with a summary of the poem. It is in seventeen Whitman-like sections with one section - "Confrontation at Bohacks (an interlude)" - carrying a title. The poem is 491 lines long and has numerous references to Walt Whitman and Hart Crane throughout, as well as individual sections (XV and XVI) devoted specifically to Walt and "Crossing Brooklyn Ferry" and Hart and The Bridge. Burke, of course, knew Hart Crane in New York during the twenties. And we, as readers, know of the centrality of 
death in the life and works of all three poets. The poem is written in the first person and is centrally concerned with the actions of this lyric I. Even if we did not know about Libbie Burke, we would still respond to this poem as a deeply personal one because of what Burke tells us about his self and actions in the course of the poem.

The poem begins with imagery of stress and testing (passing between Charybdylla and Scyllybdis), acknowledgment of old age (Burke is seventyone), and considerations of the preferability of oblivion to an afterlife. There is also a brief acknowledgment of the scene. Section II introduces more strife and tribulation into the poem in the form of a long accusatory letter from a friend who has gone sour. Burke refers to himself as "Hypochondriasis" -a person who makes his peace with his condition (illness) by studying the symptoms and learning now to "appreciate" them. That of course is what he is doing in this poem, the condition being the illness of his wife and her suffering as well as his impending loss of her. This is the personal brute reality with which the poem deals. Section III, after acknowledging the title (and hence Burke's symbolic and his wife's actual immobility), and bringing "Walt" (never "Whitman" in this poem) and "Hart" (never "Crane" in this poem) into the poem, finally gives us a series of images that characterize his condition: "I think of Pandora's box uncorked / while I was trying to untie / Laocoön's hydra-headed Gordian knot, / entangled in a maze of Daedalus, / plus modern traffic jam cum blackout" (DLC, 230-231). In these opening sections, Burke keeps exhorting himself to begin, to begin again, to begin yet again because of the difficulty and pain of the subject. In all the early sections, he is inside looking out, or inside his head. Section IV is a detailed description of what he sees from their apartment - which, of course, is the great frantic city, a place he describes symbolically as having "a restlessness unending, back and forth / (glimpses of a drive or drivenness, / from somewhere underneath the roots of reason)." Because he is looking West from his apartment and often sees the sunrise (or East) reflected in the windows of the skyscrapers, this leads him in Section V to thoughts of East vs. West and the world conflict. We could call this a kind of globalization of the conflict, stress, and tension in Burke's personal life, a movement that is very common in Whitman, but usually to different ends.

In Section VI he goes outside for the first time and ends his inside immobility; however, he is also alone since his wife can't go with him, as she would have done in the past. In going outside, on his way to the supermarket, he says he meets the hoards of people "face to face" (and the dog droppings "face to feces"). This reminds him of "The Waltman" who saw things "face to face" and of his own need to confront his own situation face to face, as Walt always assured us he did. Section VII is the "Confrontation at Bohacks (an interlude)." Bohacks is the supermarket. The "confrontation" is more stress and conflict because it turns out to be a semi-comical altercation between two crazed shoppers anxious to get through the same check-out line Burke is in. 
The "interlude" is a comic one, though Burke tells us in the gloss that he regards supermarkets as "the flowering of a civilization in decay," and so the interlude is more serious at the symbolic level than we realize. More importantly, perhaps, the episode, like most everything in the poem, really happened and, like the accusatory letter from a friend, is all part of the stress-conflict-apprehension cluster which dominates the poem.

In Section VII Burke is again outside, alone, walking, looking at "Walt's Madhatter" and "north to Hart's graceful bridge." He's walking alone at night, an uneasy time to walk in Brooklyn or Manhattan. He's out walking at night (just as he was in Section V of "Tossing") because he's somewhat tanked (full of "alky") and that makes him restless and a bit frenetic. Section IX is a flashback to when Burke was younger, living in Newark with his father and mother. We can only read this somewhat out of place flashback as purely symbolic. It's about how two tugboats cooperate to push and tow the barges first on the Hudson, then on the river they can see from their window. The tugs clearly are Burke and his wife in their intensely cooperative life together. Looking at them, he is thinking what life will be like when he is the only tug. In Section X Burke is outside again, alone, in a bar, at night, having a drink or two. Even without the long gloss which explains the symbolism of the episode, we recognize this sad scene as an image of what life will be like when Libbie is gone. In earlier days, Libbie would have gone with him to the bar, just as she would have gone with him on his walks and to the supermarket. Hence, every outside episode in this poem is charged with loss and sadness, with the apprehension that fills Burke at the sure prospect of his lonely future. Section XI is the last outside section of the poem; Burke is walking back from the bar, picking his way among the dog droppings when he meets a "dolled up Jog-Jog" accompanied by her police dog. This episode has no gloss and we can only assume that it has vague sexual as well as obvious apprehensive implications.

All the rest of the poem is inside, looking out or deeply inward- "words see but within," Burke says in Section XIII. Burke is trying to work his way out of the "Profusion of confusion" brought on by his wife's condition and the reality of her coming death and loss. "Problems pile up, like the buildings," he tells us in Section XII. In XIII he is looking at and meditating upon the city. It is here that the public part of the poem is most explicit: What are we to make of our cities? How can we understand (and live with) technology? What of progress? These are all great Whitmanian themes. But it is also here that the public and the private dimensions of the poem come together and that the theme of transcendence enters the poem. The buildings of Manhattan are described as tombstones, mausoleums, powerhouses of death and decay. Obviously Burke is seeing the city through the screen of his own loss. And he sees city building as analogous to poetry writing: "(My own words tangle like our entangled ways, / of hoping to stave off destruction / by piling up magic mountains of destructiveness.)" If we did not know about Burke's 
wife, we would turn to Section XIII for the central concern of the poem, which of course would not be Burke's personal loss, but his critical and ironic response to the great achievements of his own time and country, and to the poems and themes of Walt and Hart. There is a stunning quotation from Remy de Gourmont in Section XIII which makes one think about the poem and the poems of Burke's two predecessors in a new way: "Intelligence is an accident, genius is a catastrophe." I think these lines can really only be interpreted (and applied to the poem) in one way: Burke is certainly a genius, as Walt and Hart were; genius burdens you with knowledge few others have; "the fruits of intelligence and genius . . . are visibly beset by sinister 'side effects.'" Knowledge, as in the case of Oedipus, is often persecutional. Also, the author of this stunning statement was, in Burke's terms, both an "Olympian" (that is, a genius) and a leper - for real-so that all of his knowledge was burdened.

Here, I think, it is useful to think about Whitman and the way in which, for the most part (remembering the two crises in "Song of Myself" where Walt is betrayed by his own genius for touch and empathy), his extraordinary capacity for experience and knowledge were not a burden to him. Whitman had a lot of experience of death, and he never tried to wash death in the heavenly baths of Christianity. Burke has always seen and known more than the rest of us and tried to keep his genius for knowing from becoming a catastrophe. He says that de Gourmont always seemed "in his writings" to "so lightly" transcend his misfortune. This is certainly what Walt seemed to do with equal lightness, and what Hart tried to do but could never quite accomplish. The ups and downs, the manic swings of Hart in The Bridge, testify to the heroic attempts and failures of this ecstatic poet to do it all with words. Burke, also, would not be able to do it quite so lightly as Walt apparently could and as de Gourmont seemed to be able. Poetry may help, but it was certainly not going to enable Burke to transcend the loss of his beloved wife.

Section XIV is the most purely political part of the poem, and follows directly from XIII. From the city and technology Burke goes directly to Whitman's great theme: the manifest destiny of America, America as the future of the nations of the world. Here, as in "Tossing on Floodtides of Sinkership," Burke takes up the theme of the responsibilities of being an American and what America, the nation, is actually doing to itself and the world at large. $\mathrm{He}$ does not like what he sees (genius is a catastrophe with its burden of knowledge), and he hopes he is wrong. The political, like the other public parts of the poem, can also be seen in relation to the private because in all three Burke perceives and tries to "cope" with historical necessities: that is, the life cycle of his wife, of technology, and of his nation. One curse of genius is the ability to see to the end of the line, a trait that Whitman used with quite different results from Burke. The end that Walt's genius saw was not "the pyramidal piles of empire-building hierarchal stylized dung remains" or the pestilential city Burke envisions in Section XIII. 
Let us move on to Section XV, which is Walt's section, and examine what Burke says about what Walt saw and recorded in "Crossing Brooklyn Ferry." Section XV is a kind of brief (forty-one quotation-filled lines) analysis of and commentary on "the Waltman's testimony" from Burke's personal and public twentieth-century perspective. The personal perspective is what we get in the earlier parts of the poem, but XV is mostly concerned with the public significance of "Crossing Brooklyn Ferry"-the attitude toward history Burke finds expressed in it, and especially the attitude toward America. The poem goes around between Walt (the promissory), Hart (the nostalgic), and Burke (the apprehensive). Walt clearly believes; Hart would like to believe, but can't really and tries to recreate belief with metaphor and self-hypnotic lyric ecstasy; Burke is apprehensive: he can't write away his personal loss and he can't believe Walt anymore and he won't do what Hart did.

Burke's treatment of Walt's poem acknowledges and discredits it and him at the same time. It's stuck in ambivalence. Burke correctly shows how dependent Walt is on the eye (seeing, eye crossing, as opposed to doing, ferry crossing), and how he too must deal in appearances. He points out the great irony of Walt's certainty that future generations would be "crossing and recrossing / on the ferry which no longer runs." He focuses on Section 6, where Walt catalogues "his vices / as though basking on a comfortable beach," and writes of Walt's "tricks" of "ideal democratic promiscuity" and "ideal man-love." He says that Walt was "blindly bland to the promotion racket stirring already all about him" and that Walt "bathed in the waters" without reference to their "imminent defiling" (which seems a bit excessive: who in 1856 could possibly even imagine the massive pollution of the twentieth century?). And finally, he says of Walt's testimony that "He sang as though it were all his - / a continent to give away for kicks. / And such criss-crossings made him feel pretty damn good." Then Burke ends Section XV with a wonderfully ironic and still ambivalent interlacing of echoes from the last section of "Crossing Brooklyn Ferry":

Flow on, filthy river, ebbing with flood-tide, and with ebb-tide flooding.

Stand up, you feelingless Erections,

Fly on, O Flight, be it to fly or flee.

Thrive, cancerous cities.

Load the once lovely streams with the clogged filter of your filth.

"Expand,"

even to the moon and beyond yet.

"There is perfection in you" in the sense

that even empire-plunder can't corrupt entirely. $(D L C, 244)$

Walt's section is followed by Hart's section (XVI), the penultimate one of the poem. The overall movement is from Walt to Hart to Burke (the "apprehensive whosis"). This is both a historical movement and a movement through 
attitudes from the promissory (looking forward) to the nostalgic (looking back) to the apprehensive (looking right at it). Hart's section, like Walt's, is built of quotations (here from The Bridge) plus commentary. Like Walt's section, it acknowledges and discredits at the same time, showing that Hart tried, by the "logic of metaphor" to "span whole decades of division." At the end of Hart's section, Burke returns to himself (the primary locus of the poem) as the "apprehensive whosis" who is still talking of crossing on a river when men have crossed space and circled the moon; he returns to Manhattan as seen from Brooklyn, where it appears as a set of signs (that is, as real and symbolic) spelling out the genius of technology, and, for the first time since the beginning of the poem, he returns to the accusatory letter from the friend gone sour.

The final brief section of the poem backs away from the heavy public issues of the previous three sections and returns to the sensory and the personal-inside looking out rather than completely inside the head and deep in the world of words (poetry). The section opens with a classic city image: gridlock, the traffic congestion when crossing into the city in the A.M. and leaving it in the P.M. Since Burke says that "Many's the driver that crosses cursing," one has to wonder if this whole passage is not symbolic, referring to the agonizingly slow crossing over of his wife Libbie. Gridlock is also a wonderful image for the near paralysis and immobility Burke refers to early in the poem and in his "Introduction." The next few lines refer again to the city seen from the apartment at sunset and nightfall and are pure examples of eye crossing. The poem ends with more pure eye crossing images as Burke looks first West to the lights in the harbor and then right to the "towerings of Lower Manhattan." But these quite lovely sensory images and perceptions are not allowed to remain pure: are the lights just lights and "pure of human filth"? And Burke's last response to the city is that it is a "catastrophe." This drives us back to the quotation from de Gourmont that "Intelligence is an accident, genius is a catastrophe." The city represents the genius of technology and is a catastrophe in that sense. Burke surely recognizes himself as a genius, and much of the poem has been about the catastrophe of what he knows. The situation he is in is personally catastrophic, beyond the reach of words and knowledge, a brute ironic fact of his existence. Neither the promissory nor the nostalgic nor Hart's logic of metaphor nor Walt's tricks will make it go away or enable him to transcend it. No attempt is ever made in the poem to transcend it. Walt's way and Hart's way are both acknowledged and rejected. We have to understand that both Walt and Hart have been responded to in profoundly personal (private) and public ways.

What has not been rejected is the action of making poetry out of catastrophe, which is certainly what both Walt and Hart also did. As Burke has pointed out elsewhere, when Hart could no longer make poetry out of the catastrophes of his life, he killed himself. As readers of Whitman know, Walt was always able to make poetry out of catastrophe-both his own and that of 
his nation. Burke has written brilliantly about how Walt did this in "When Lilacs Last in the Dooryard Bloom'd." Burke has done this in "Eye Crossing - from Brooklyn to Manhattan," but instead of ending on the promissory he ends with apprehension and resembles William Carlos Williams (just as this poem, in its form, resembles the Williams we encounter in Paterson). Knowledge leads to an apprehensiveness that cannot be transcended: it can only be mixed with irony, as in the closing lines of Section XV quoted above. Burke's poem is very accurately entitled, since all that is really available to him is eye crossing and words. Burke does not exhort us with verbs, as Walt does in Section 9 of his testimony (flow on, frolic, cross, stand up, throb, sound out, live, play, consider, fly on, receive, diverge, come on, flaunt, burn, thrive, expand, keep): he presents us with images of stress and frustration (the traffic) and with problematic images of "Walt's Madhatter" - the city as a vast accumulation and producer of a monument to human filth which, ablaze with light, looks like a catastrophe (a huge fire) and "doubtless ... is" a historical one.

\section{III.}

Burke's encounters here with the Waltman, as with the Hartman, have been complex and profound. It is not easy to reject Walt: he's so loveable and reassuring and poetically ravishing that one always wants to believe him and believe in what he says, but. ... It is this "but" that will occupy us as we consider Burke's final two encounters with Whitman in his Helhaven Satire (1971, 1972, 1974)11 and in his Bicentennial lecture, "Towards Looking Back" (1976). ${ }^{12}$

It is inevitable that Burke would be attracted to satire. The kind of knowledge that is the basis of great satire-like Swift's Gulliver's Travels -is the curse of genius. Satire provides a way of using this knowledge which keeps it - the knowledge-from becoming too destructive because in a satire the knowledge can be used to both destructive and constructive (or apparently corrective) ends when the satire is universal rather than purely topical. The theme of Burke's satire - technological pollution and rationality as man's tragic destiny -is certainly universal and global in nature, and more so every year as more and more developing nations "modernize" in imitation of the advanced industrialized nations of the world and so contribute to the destruction of the resources that make modernization possible. In Burke's terms, we could say that more and more nations imitate the history and development of the America Whitman celebrated, with more and more disastrous results. This, in fact, is the theme of Burke's satire: that Walt's dream has become our nightmare, but that hypertechnologism will still try to redeem this dream with more technology.

Burke first wrote up his Helhaven satire in 1971 in an essay entitled "Towards Helhaven: Three Stages of a Vision." The subject of the satire is 
"technological pollution," or, in Burke's neat ironic phrase, the proposition that "man's entelechy is technology," and that in the second half of the twentieth century the great creative genius of technology has become destructive on such a massive scale that it threatens to destroy the very planet it helped to civilize. Burke's first version of his satire is relatively brief (fourteen pages) and essentially sums up a number of ideas that had been present in his work from the 1930s on. Technology and its attendant bureaucracies and problems (especially pollution) have been major concerns of Burke's since $A$ Grammar of Motives (1945). What is new is the satiric Helhaven idea in which the elite of mankind, having polluted the planet earth with their technology, use this very technology to migrate to the moon and create a second home there, leaving the polluted earth behind, along with the millions (billions?) who could not afford to migrate.

Whitman does not figure in this first version of Helhaven, nor in the incidental uses of it in Dramatism and Development (1972), but he is the central figure in the second, much longer and more elaborate version of the satire which Burke published in 1974 in an essay entitled "Why Satire, With a Plan for Writing One." The whole of the earlier essay is incorporated into the later, longer one. There, the object of the satire is still "technological pollution" but to that object (or subject) Burke has now added Whitman and his vision, specifically Whitman's ecstatic, affirmative vision of the future as he expressed it in these lines from "Song of the Open Road": "I know not where they go, / But I know that they go toward the best -toward something great." It is the ironic fulfillment of this prophecy in the twentieth century that is the object of Burke's serio/comic anti-Whitmanian satire. Here is how Burke puts it:

The [satire] involves certain implications in such poems of Whitman's as "The Song of Occupations," "The Song of the Open Road," "The Song of the Broad-Axe," and "O Pioneers" [sic]. But they are to be seen satirically in the light of subsequent developments. Considered thus, they are reducible to a proposition of this sort: Since they are celebrating almost an orgy of construction, and since there is no construction without destruction, it is now clear that those poems were joyously ushering in the very era of care-free destruction now nearing its careworn culmination in environmental problems due to technologically caused pollution. Whitman's poems of that sort were in effect (or at least for purposes of satire they could be viewed as) utterances by a great prophetic bard of real estate promotion. Of course there is more to Whitman than that, and I am among those who have said so. But for reasons that will become apparent my project needs him badly, in the role I have assigned him. And now that all the territory within our borders has become the transformation of nature into real estate of one kind or another, we need but ask ourselves how, by putting satire in place of his easy idealism, we can reclaim and thus enjoy once more the accents of the exultantly promissory. (WS, 315)

Naturally, there is more to Burke's satire than this somewhat ironic use of Whitman would seem to indicate, especially the heavily ironic final sentence. The central idea of Burke's satire has to do with the relationship between rationality and technology and the way in which "rationality attained its mater- 
ial counterpart in the rationalized procedures of the machine," and in this way ceases to be an "ideal of the few" and becomes instead "a problem of the many." "Materialize an ideal and you get a problem, including the ultimate ironic fact that an excess of rationality as so defined adds up to a new level of irrationality" (WS, 319). What is being satirized here is a tragic perception of the human condition, or the fact that man's major asset is going to be the basis of his destruction. It is like the curse of tourism and fame: the very things that bring the tourists bring what will eventually destroy or degrade the place; and fame (either of a place or a person) is such a liability in these days of media hype that many are destroyed by what they seek. Burke, of course, is contemplating this irony or paradox on a global scale, and his satire works "on the assumption that, by carrying such speculations to the end of the line, one keeps the admonitions alive." "In this way," Burke says, "satire would enable us to contemplate a situation to which we might otherwise close our minds, by self-deception, or by dissipation" (WS, 321).

Much of "Why Satire" is concerned with developing specifically Burkean ideas which are very important to an understanding of Burke's later work on language and technology, but are not particularly pertinent here in the discussion of Burke's final encounters with Whitman. The same is true of the details of Burke's delightful satire about building a culture bubble on the moon to which the masters of technology can migrate once they have polluted the earth with their technology, leaving all the rubble behind. It is the idea behind the satire, rather than the details of it, that must concern us here, for that is precisely where Burke's encounter with and use of Whitman comes in.

We need to remember that the basic plan for the satire was well worked out some years before Whitman was inserted to become part of it, as well as one of the objects of the satire. Here is the way Burke introduces Whitman into his satire and justifies the use of him. It is technology he is satirizing, and he says that the

task of the satirist is to set up a fiction whereby our difficulties can be treated in accents of the promissory. Whitman in his accents of gladness, had given us the clue:

... I know not where they go,

But I know that they go toward the best-toward something great.

The satirist's quasi-solution would track that down, not just leaving it en route as with Whitman's words, but to the end of the line.

There are further tangles, still to be considered. But for the moment let us be content with what opens up before us: a post-Whitman, neo-Whitman vision carrying the ambiguities of construction and destruction into areas of pioneering and colonization unthinkable to the technology of Whitman's times. Thus was born the project of Helhaven, a scientifically designed culture bubble on the moon, and also involving a high degree of technical organization, whereas Walt was but content to loaf and invite his soul. (WS, 315-316) 
Whitman, in other words, is made a spokesman for a historical development he did not cause, but which he ecstatically affirmed in many of his poems as part of the manifest destiny of the United States, whose destiny, he said, would show the way for the rest of the world. It is the ironic fulfillment of these historical prophecies, and Walt's prophecies themselves, that become the objects of Burke's satire: the somewhat naively affirmative attitude toward technological development, and the positive future which is found in Whitman's poetry (according to Burke). This attitude is not unique to Whitman, but Whitman has been chosen to represent it, and it is for this reason that Burke says he "badly needed" Whitman for his project and so added him to the Helhaven satire.

Whitman is next mentioned in the essay some pages later when we are told that The Master - the leader who formulated the Helhaven projects and who writes the two mock Whitman poems at the end-had begun "as a disciple of Whitman and had got into dire trouble until he found a way out" (WS, 322). The way out was to take the strong promissory accents of Whitman's poetry and transfer them to the Helhaven project, using it as the "something great" Whitman affirmed as our goal. One of the ironies here, of course, is that only the few, rather than the many Whitman was addressing in "Song of the Open Road," can ever go to Helhaven, and further, Helhaven by its very name-is not the "something great" Whitman promised in his poem.

Whitman is mentioned (used) again a few pages later-again in relation to The Master, the "generating spirit of the whole [Helhaven] enterprise." This time we are told that The Master had "begun as a Whitmanite, elated in poetically cataloguing the revolutionary environmental changes that the predatory European invaders had visited upon this continent. When it gradually dawned upon him, if you could call it a dawn! (Where did we hear that before?), that Walt's dream was becoming a nightmare, he was desolate." The Master needed a way to affirm that "Whitman's promises [were] as good as ever" (WS, 326). This he did, of course, in the Helhaven project whereby "the ills of technology could be left to soil the Earth, the virtues of technology could raise transcendentally elsewhere" (in the culture bubble on the moon).

There are two other passing references to Whitman and The Master which I want to quote before turning to the two mock-Whitman, burlesquing "Effusions" of The Master with which Burke ends the essay. Recapitulating the steps by which The Master arrived at his "final solution," Burke says that it was "[t]he growing evidence that pollution [manifested] the fatal costs of technology [that] had first caused The Master, the Personalist Supreme, to lose his faith in the Whitmanite ideal of conquering a continent by Ecstatic, headlong, anti-conservationist upheaval" (WS, 329). I leave this without comment as an example of how Burke is using Whitman here. As to this use of Whitman, Burke admits that Whitman, if he were still among us, might with some justice "object to discussing certain poems of his in terms of vatic 
real estate promotion" (WS, 330).

And now we move to what Burke calls "Apocalyptic Affirmation (Effusions of The Master)." These "effusions," he says, while they were "obviously written under the influence of his Master, Walt Whitman, even to the extent of outright borrowings and sometimes transforming lines from Leaves of Grass, they were conceived in the light of subsequent developments which Walt's ecstatic salesmanship, with all its stress upon the future, could not foresee ..." (WS, 331). These unforeseen developments and problems Burke describes as follows: the technological enterprise, with its "rationality of technics," has "so greatly progressed (now) that, everywhere you turn, it raises problems (thus in effect transforming our greatest hope for salvation of mankind, rationality, into major incentives making for cults of the irrational)" (WS, 331). (This, by the way, very succinctly states the most serious theme of the satire, a theme that Burke will return to in more detail in his Bicentennial lecture.) Now, briefly, back to Whitman before going on to the "effusions" in which The Master "transformed Walt's over-idealistically easy-going promises for all into a more realistically apocalyptic Vision of Division" (WS, 332). Referring back to the "unforeseen development" in technology, Burke says that Whitman hit upon a "gladsome way of helping out" with this problem, and again quotes a line from his "favorite" Whitman poem, "Song of the Open Road": "it is provided in the essence of things that from any fruition of success, no matter what, shall come forth something to make a greater struggle necessary." The Master, he says, took this line and went on from there. Which brings us to the two "effusions."

Burke is a master of irony and comedy, especially in his poetry. We see both of these traits in the first of the effusions, which, Burke tells us, "stresses the exhilaration of the Vision's promise (for the Chosen)" (WS, 333). It is entitled " 'O Lesson Opportune' (The Master's Call)." It is too long (eightyseven lines) to quote the whole of it, but I will quote a few lines so one can get the flavor of them:

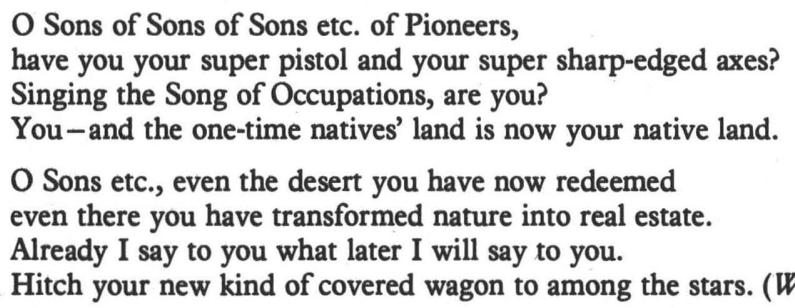

And so forth throughout, mixing bits of lines from Whitman in ironic contexts, altering lines slightly for comic, ironic, and satiric purposes, and in general taking the promises of Whitman and fulfilling them with ironic and historically true later developments, usually having to do with the displacement of the Indians, the destruction of natural resources, and the conversion 
of wilderness into real estate. The poem moves steadily toward its ironic conclusions, which is the call to the chosen few to follow The Master, who speaks in the promissory accents of Whitman in "Song of the Open Road": "towards home in (hail! Heaven!) in Helhaven, home!" (WS, 335). Burke is at his comic, ironic, satiric best in the first of the effusions. The tonal balance between outrage and laughter is well maintained; he has caught the promissory accents of Whitman very well, imitated his style very accurately, and quoted wonderful lines from the different poems which are mixed in with later historical facts in a kind of crazy, often hilarious appropriateness.

The second effusion is not so successful. It is certainly not very Whitmanian, until the very end, and is somewhat overly obvious. It is entitled " Far, far off the Daybreak call' (Night Thoughts of the Master)," and is an ironic celebration by The Master of the rubble, filth, and massive pollution that is left behind when the chosen few go "Onwards, Outwards, and UP!" to Helhaven. In fact, the poem expresses the loathing on the part of The Master for what is left behind (the Masses, the massive pollution) and has no counterpart anywhere in Whitman. However, it does have a central place in the satire, and is a most appropriate conclusion to it as the Chosen Few celebrate their escape from the earth they polluted and their arrival in Helhaven, where they may contemplate from afar the mess they left behind. ${ }^{13}$

The most obvious contrast to the way in which Burke has used Whitman here is to be found in Allen Ginsberg who, I think, expresses a reaction many of us have to Whitman, which is nostalgia for the "lost America of love," nostalgia for the lost promises and hopefulness, for the broken promises of history, nostalgia for the closing of the open road, especially the open ontological road that had such a powerful effect on Lawrence, for the closing of the frontier, and nostalgia for the lost sense of unity (of the self, between selves, between self and nation, self and cosmos, life and death) that pervades Whitman's poems and gives them much of their power. This sense of nostalgia is much more obvious in Burke's two Whitmanian poems, so it isn't that he has not experienced it reading Whitman, but that he has suppressed it here in the interest of his satire. Burke himself has expressed considerable nostalgia for what we have lost to history (beginning in the 1930s) and has written many powerful exhortations to us, full of the promissory accents of Whitman, to not lose sight of and to keep moving steadily towards the better life. We should keep in mind, when thinking about Burke's Helhaven satire, what he said about satire in general, way back in Attitudes Toward History: "THAT THE SATIRIST attacks in others the weaknesses and temptations that are really within himself. . . " (WS, 317). 
Burke's last encounter with Whitman occurs in his dense and complex Bicentennial Lecture, "Towards Looking Back" (1976). As is most appropriate for a Bicentennial Lecture, "Towards Looking Back" is concerned with how we, as twentieth-century Americans, conceive of America and of ourselves as Americans, as compared and contrasted to how Henry Adams and Walt Whitman conceived of America and themselves as Americans. There are some references to other earlier writers, but the bulk of the essay, after the preliminaries, is concerned with The Education of Henry Adams and Leaves of Grass. The preliminaries are important because they introduce the components of the discussion: the wilderness, the Indians, the "civilizing" domesticating process, technology, and democracy; America as a nation, how American writers conceive of themselves and their work in relation to their country; and, finally, America and the world, or the national and global.

As usual in a really good Burke essay, there is a lot going on here, but basically what Burke is concerned with is America, technology, and history. It was superior technology that enabled Americans to domesticate (despoil) the wilderness and destroy the Indians and their way of life. America and American democracy are not really separable from technology. Whitman put his faith in all three and, according to Burke, it was in "Walt Whitman, Celebrant" that "the half-responsive, half-adversary 'Americanism' that grew out of the 'wilderness' and its despoliation ... . reached its poetic fulfillment in Whitman's way of being nationalistically infused by the spirit of Emerson's moralistically pragmatic transcendentalism" (TLB, 175). It is Whitman who has given us "a truly 'American' song, even in the strictly political sense" $(T L B, 179)$. "Whitman's . . . stylistics of promissory assertion put the stress not upon the contrast between rival ways of life on this continent (the white man's and the red man's) but upon a contrast between the vestiges of European feudalism and the boisterous development of bourgeois democracy pari pass $u$ with the expansion of white settlements" (TLB, 179). Without trying to summarize Burke's rather complicated presentation of Whitman, we can move to his conclusion, which is that Whitman's "entire life and work" can be seen as "a kind of national conclusion" which comes to a head in Whitman's "gospel of Democratic brotherhood, which will first unite the nation and then the world ('all nations, and all humanity')."

Fifty years later, Henry Adams saw things differently, moving from a global scheme based on politics to a global scheme based on technology (the dynamo) and technological innovation. As Burke points out, Adams was not so much concerned with what it meant to be an American but with "what it is to be what comes next" $(T L B, 175)$. Put somewhat differently, Adams perceived that history and technology were moving us toward transnationalism and that identity could no longer be worked out in purely national or even political terms. Though Burke does not put it this way, he implies that Adams 
clearly saw that Whitman's song was becoming an anachronism - that is, largely rhetorical, or "sheerly symbolic exercising" (TLB, 186).

Burke's conclusion is entirely concerned with technology and the fact that we can no longer be solely or primarily concerned with what it means to be an American because now, seventy years after Adams,

... all mankind collectively confronts a platitudinously inescapable situation, emerging with the qualitative step from the quantitative technological multiplicity of Whitman's day to that of Henry Adams', and now dreadfully obvious in the Era of the Atomic Pile, along with assists from chemical and bacteriological advances in weaponry and the likelihood that applied science (Adams' Dynamo) will soon have "perfected" the potentialities of harnessing even the weather for genocidal purposes. (TLB, 187)

Here is the final paragraph of the essay in which Burke again takes up the "Bicentennial implications of the step from Whitman on democratic brotherhood to Adams on the later developments of technology":

The essential "rationality" of our inventions is what raises much of the trouble. For mankind is in trouble indeed when the great accomplishments of human rationality raise more problems than can go well with Whitmanlike accents of the promissory. In technology, we confront an objective fulfillment, since it is so rational in its essence; yet its very rationality is but a caricature of human reasonableness. When the implementations of rationality multiply our problems, we are conflicting with rationality itself. I would call such vexations the universal puzzle with which the Dynamo now Bicentennially confronts us. $(T L B, 189)$

The opposition between Adams and Whitman is deeply symbolic for Burke because the same two voices have argued inside his head for most of his publishing life. The "promissory" voice of Whitman is everywhere in his books and especially in his persistent belief in the power of knowledge and the value of criticism. However, the ironic rational voice of Adams keeps whispering, or sometimes shouts to him that knowledge is powerless and the self is helpless against the relentless compulsion of rationality to perfect itself in technology, even if this technology can destroy all the life that created it. This is the "universal puzzle" only rationality itself can identify, understand, and try to solve. If in fact it does solve it, it will be in part because of Whitman's persistent "promissory" voice. Eliminate Whitman's promissory voice and you have only cynicism, extreme misanthropy, debunking, and despair-none of which have ever been characteristic of Burke's work.

In some ways, Burke's encounter with Whitman in this essay is the most profound and most appropriate one he has had because Whitman - our greatest poet, our first great poet, our national poet-really does represent and express precisely what Burke says he does in Leaves of Grass. No thoughtful American reader of Whitman in the last half of the twentieth century can read Whitman and fail to ask the political and historical questions that Burke does. Ontological questions having to do with Whitman's idea of the self are quite another matter, as D. H. Lawrence correctly pointed out many years 
ago; Burke has never been much interested in these and has never really addressed them, which is one reason he seldom mentions "Song of Myself," Children of Adam and other such poems. Even Burke's frequent use of "Song of the Open Road" shifts the emphasis from ontological to political, histori$\mathrm{cal}$, and even ecological matters. Burke's encounter with and use of Whitman here is much different from his use of him in the Helhaven satire, though he makes many of the same points in both essays. There is no attempt to satirize or burlesque Whitman here, no attempt to discredit Whitman's authentic voice, nor to suggest that he may have been whistling in the dark. If, more than a hundred years later, we can no longer believe in the America Whitman celebrated in the same way he did, his songs, his Leaves are not necessarily vitiated. If Burke, himself something of a celebrator (though always ironicin the great modern mode), can't be the "celebrant" Walt Whitman was, he can, as he does here, recognize celebration as one of the essential human "offices," and he can lament (another essential human office), as many of the rest of us do, our inability (not our failure) to celebrate our country and its future the way Walt did. ${ }^{14}$ The bomb, one of the great achievements of rationality and technology, one of the great creations of human genius, keeps exploding in our brains, and the celebratory in us suffers some from radiation sickness.

What can we say, then, of Kenneth Burke's encounters with Walt Whitman? To summarize the obvious, we can say that these encounters took a lot of different forms, from the initially superficial, to the intensely criticaltheoretical, to the monothematic (Whitman, technology, and the promise of America), to the deeply personal and poetic, to the satiric, and finally to the personal/national-which is to say, Whitman becomes absorbed into the deepest concerns of Burke's later (post-1966) work with language, rationality, and technology. To state another somewhat obvious point, we can say, as we could probably say of any genius, that Burke's encounters with Whitman changed as his interests changed over the years, and that he always used Whitman to his own ends, subordinating Whitman, using him to support his (Burke's) own ideas and development. This is probably most obvious in the Helhaven satire.

Although I said at the beginning that I was not going to discuss influences, it does seem clear that "Song of the Open Road" has had a long and powerful influence on Burke, not just as a model poem (in "Tossing on Floodtides of Sinkership," "Eye Crossing," and other poems), but as an essential American text, one that gives us a way to think about America and being an American, as do The Great Gatsby, In the American Grain, and Absalom, Absalom! We can say also, thinking of just what Whitman texts Burke actually refers to and uses, that he either did not really know a lot of Whitman, or was only interested in what met his immediate needs at a given point in time. Even in "Policy Made Personal," where he seems to be ranging over 
a lot of Whitman poems, he is really only ranging over a lot of Whitman lines, looking for different kinds of images, as if he were working out of a concordance, and working out a thesis about how poetic images function.

In other words, we do not go to Burke for a reading of Whitman (though there are a lot of interesting hints and clues as to what Whitman is about in "Policy Made Personal"); we do not go to Burke for knowledge about the making of Leaves of Grass from the 1855 edition on, or for a detailed reading of any poem except "When Lilacs Last in the Dooryard Bloom'd." Burke really does subordinate most texts to his own interests or theories, and he seldom analyzes whole poetic texts, but rather fixes on some element in them which will serve his immediate needs. Most of the whole literary texts Burke has analyzed-often with great, if highly specialized, brilliance-are novels or plays. But even there, one tends to take a theory or a methodology away from Burke's reading, rather than a usable specific reading. With a few exceptions, then, these encounters with Whitman tend to tell us more about Burke than they do about Whitman except insofar as Whitman still represents a powerful and persuasive attitude towards America and the American dream. If it were not so powerful and persuasive, Burke would not spend so much time trying to qualify it, even as he begins to succumb to it yet again, as so many of the rest of us do every time we submit ourselves to those passionate and persuasive lines and listen to Walt assuring us that it is all true because he has been there before us and checked it all out. We do so want to believe him. If nothing else, Burke's encounters with Whitman testify to the enduring power of his poetry and the deep ambivalence of the American mind.

\section{State University of New York, Geneseo}

\section{NOTES}

1 It is nearly ten years later before we find any further references to Whitman and any discussion of him. See Attitudes toward History, Third Edition (Berkeley: University of California Press, 1984 [1937]), 3-18, in which Whitman, James and Emerson are discussed as examples of "Frames of Acceptance." It is probably not important to try to determine when Burke first read Walt Whitman since this essay is solely concerned with his encounters with Whitman in print, and especially with his serious encounters. For the record, I note here that Burke first refers to Whitman in a passing way in print in the "Musical Chronicles" he wrote for The Dial in the late 1920s. See The Dial 86 (1929), 178, 243. For a discussion of these "Musical Chronicles," see Denise M. Bostdorff and Phillip K. Tompkins, "Musical Form and Rhetorical Form: Kenneth Burke's Dial Reviews as Counterpart to Counter-Statement, " Pretext 6 (Fall/Winter 1985), 235-252.

2 The Philosophy of Literary Form, Third Edition (Berkeley: University of California Press, 1967 [1941]), 118, 316.

3 Leaves of Grass One Hundred Years After, ed. Milton Hindus (Stanford: Stanford University Press, 1955). Burke's long essay is on pp. 74-108. Other essays in the book are by William Carlos Williams, Richard Chase, Leslie Fiedler, David Daiches, and J. Middleton Murry. 
4 “Othello: An Essay to Illustrate a Method," Hudson Review 4 (1951), 165-203.

5 This poem originally appeared in The Nation (2 June 1969), 700-704.

6 The Rhetoric of Religion (Boston: The Beacon Press, 1961); hereafter abbreviated “RR.”

7 Language as Symbolic Action, Essays on Life, Literature, and Method (Berkeley: University of California Press, 1966); hereafter abbreviated "LASA."

8 Lawrence Buell, Literary Transcendentalism: Style and Vision in the American Renaissance (Ithaca: Cornell University Press, 1973), 328-330.

9 Collected Poems, 1915-1967 (Berkeley: University of California Press, 1968); hereafter abbreviated "CP."

10 This poem exists in two versions. The first and shorter version is identified in note \#5. The second and longer version appears under the title "An Eye-Poem for the Ear (With Prose Introduction, Glosses, and After-Words)" in Directions in Literary Criticism: Contemporary Approaches to Literature, ed. Stanley Weintraub and Philip Young (University Park: The Pennsylvania State University Press, 1973), 228-251 (hereafter abbreviated " $D L C$ "). All my comments are based upon and refer to the second, longer version of the poem and have drawn heavily upon Burke's commentary upon his own poem. Burke has always been a great selfcommentator, which is an indication of the highly reflexive nature of his genius and of his compulsion to always make sure he has set the record straight. The occasion for this commentary on his own poem is as follows: A long time friend and admirer of Burke's-Henry Sams, the former chairman of the English Department at Penn State-had given Burke's poem to his graduate seminar, without telling them who wrote it, and asked them to comment on the poem. Burke's own commentary is a response to their commentary. All of this creates a very curious situation because the poem is deeply personal and arises out of the situation I have described.

11 Burke's Helhaven satires were published as follows: "Towards Helhaven: Three Stages of a Vision," The Sewanee Review 79 (1971), 11-25. This is the shorter version of the satire and makes no use of Whitman. The central ideas of this satire had been on Burke's mind for some time and are related to his thinking about technology - a subject that has preoccupied him for the last twenty years. Pieces of this satire also appear in Dramatism and Development (1972), the published version of the Heinz Werner Lectures Burke gave in 1971 at Clark University. The longer version of the satire was published as "Why Satire, With a Plan for Writing One," in The Michigan Quarterly Review 13 (Winter, 1974), 307-337 (hereafter abbreviated "WS"). It is in this version that Whitman appears, and my discussion is mostly based on it.

12 "Towards Looking Back," Fournal of General Education 28 (Fall, 1976), 167-189 (hereafter abbreviated "TLB"). This is the published version of The Joseph Warren Beach Memorial Lecture which Burke gave at the University of Michigan in April, 1976.

13 It is difficult to do justice to these two mock-Whitman poems without quoting them at length. The first and most successful of the two-" $O$ Lesson Opportune' (the Master's Call)" - works especially well because of the historical, almost dramatic, ironies which operate throughout to cancel or work against the ecstatic affirmations of Whitman's wonderful lines, and because of the skillful mixing in of twentieth-century facts amongst the Whitman phrases and lines. Most of the lines and phrases which Burke quotes are from "Pioneers! O Pioneers," "Song of the Broad Axe," and "Song of the Open Road." Burke's second poem is much less successful as a mock-Whitman poem but quite successful as a conclusion to the satire. There are few Whitman lines in this poem because it is really an anti-Whitman poem, rejecting what Whitman spent so many lines and poems accepting: namely the masses. The poem is written by an elitist - the Master - and rejects what is left behind on earth when the elitists, having polluted the earth, depart for Helhaven. What is left behind is described in often rather coarse images of a kind one would never find in Whitman. The poem is only Whitmanian at the end 
when Burke quotes some lines from "As Adam Early in the Morning" and uses the ecstatic (but mocked) rhetoric of Children of Adam and perhaps "Passage to India" to celebrate (ironically) the ascent of the elite to the culture bubble on the moon, the Helhaven of the title, the new antihome of the technologists. Anyone who has gotten this far in this essay should go to the library and read these two poems if he/she wants a good sense of how Burke has encountered and used Whitman here.

14 See Burke's essay "The Seven Offices," in Attitudes toward History, 353, 375. 